Article

\title{
Sustainable Road Maintenance Planning in Developing Countries Based on Pavement Management Systems: Case Study in Baja California, México
}

\author{
Marco Montoya-Alcaraz ${ }^{\circledR}$, Alejandro Mungaray-Moctezuma * and Leonel García \\ Faculty of Engineering, Universidad Autónoma de Baja California, 21280 Mexicali, Mexico; \\ marco.montoya@uabc.edu.mx (M.M.-A.); leonel.gabriel.garcia.gomez@uabc.edu.mx (L.G.) \\ * Correspondence: alejandro.mungaray@uabc.edu.mx; Tel.: +52-686-566-42-70
}

Received: 30 November 2019; Accepted: 14 December 2019; Published: 19 December 2019

\begin{abstract}
The objective of this research is to develop a useful procedure that allows the collection, analysis, processing and updating of pavement conditions data, with the vision of generating inputs for the implementation of sustainable strategies for maintenance and rehabilitation of roads, based on pavement management systems. The relevance of this proposal lies in the fact that road management agencies in most of the developing countries have limited resources, staff and data to plan the interventions carried out on road networks. The proposed model comes from a work that has been done since 2014 to date, on the Centinela-La Rumorosa Highway, located in the state of Baja California, Mexico. Results integrate data gathered from analyzing the surface and structural conditions of its pavement and the study area, as well as the operating conditions of the road, including a georeferencing process in order to determine critical points in the network, and simulation to determine the effects of maintenance work carried out annually. It is concluded that the proposed planning model contributes to the improvement of highway performance, since it allows planning and administering the allocation of resources in making appropriate maintenance and rehabilitation decisions. Additionally, it allows to generate valuable inputs for pavement management systems implementation. The foregoing allows road management agencies in developing countries to provide a quality transportation system to their users.
\end{abstract}

Keywords: pavement maintenance and rehabilitation; pavement management systems; pavement survey data analysis; road administration

\section{Introduction}

An important number of agencies, companies and organizations have adopted a sustainable approach that focuses on the economic, environmental and social impacts in planning and decision-making [1]; on this matter, pavement management has become increasingly important to the extent that, with the passing of time, roads age and deteriorate. On the one hand, roads have been designed and built for a useful life and it is necessary to take actions to increase their service cycle; on the other hand, funding levels are increasingly limited and better resource management is required in order to attend to a global mobility system that is mostly focused on the use of roads [2]. Pavement Management Systems (PMS), are the set of procedures and tools that are intended to assist road management organizations in the systematic application of processes related to pavement management, particularly the identification of optimal alternatives for network conservation in the short and medium term, as well as the development of maintenance and rehabilitation (M\&R) programs, which translate into significant benefits, both technically and economically [3]. However, results reliability of these systems depends on the quality and quantity of data that are provided to it and the calibration of the 
models to local conditions. In developing countries, road management agencies have limited resources and staff, and for this reason, obtaining such inputs implies a greater effort and challenge. In that case, Mexican administrative agencies have not been able to adopt a pavement management approach. Therefore, road maintenance and rehabilitation works are carried out reactively, and not proactively, once surface and structural failures occur; in general terms, it becomes complex for one-way managers to define a preventive strategy.

As a result of the foregoing, as of the year 2014, a project which seeks to improve planning and decision-making regarding the $M \& R$ of a road section began. This project locates in a mountain range of Baja California, Mexico. The objective of this research is to develop a useful procedure that allows the collection, analysis, processing and updating of pavement conditions data, with the vision of generating inputs for the implementation of sustainable strategies for M\&R of roads, based on pavement management systems.

\section{Background}

Road construction consumes a large amount of non-renewable resources [4]. To address this problem, several sustainability assessment programs have been developed, such as the Greenroads program [5], the FHWA's Infrastructure Voluntary Evaluation Sustainability Tool (INVEST), the Sustainability Programme of the European Union Road Federation (ERF) [6] and the Civil Engineering Environmental Quality (CEEQUAL) [7]. These programs contain strategies and tools to implement sustainability criteria at different stages of the pavement life cycle, that is, material production, design, construction, operating phase, maintenance and end of life [1]. In this regard, several studies have carried out pavement sustainability concepts or road sustainability for contributions that improve economic, road social and environmental aspects. For example, Mao et al. [8] provides a method to improve pavement performance sustainability by a reasonable traffic flow assignment; Corriere and Rizzo [9] provide guidance for a methodological approach of sustainability in road design; Farooq et al. [10], Yang et al. [11] and Demasi et al. [12] analyzed factors that contribute to traffic safety; in environmental sustainability, Montgomery et al. [13] provide a wide range of ideas and options to improve the inclusion of environmental sustainability throughout the road project cycle.

However, the implementation of sustainability in M\&R strategies requires greater control because it impacts different parts of the pavement cycle. Pavement management is a discipline that encompasses activities involved in planning, design, construction, evaluation and conservation of the pavements in a road network [14]. Background studies in pavement management and sustainability have examined PMS programs in order to recommend network maintenance treatments based on general conditions of the pavement surface, traffic data, road section, structural conditions and other performance indicators [15]. It is important to mention that this research applies the concept of pavement management of roads, highways and major roads. Nevertheless, few studies have applied pavement management activities on urban areas $[16,17]$ and pavement sidewalks [18], proving its reliability in these areas.

It is worth pointing out that most of the data are gathered through pavement condition studies where information on pavement conditions is collected through automated and specialized means; this data generates a scale or condition index. However, the index used depends directly on the agency's economic resources and its ability to obtain and interpret such data [19]. Since the model simulates future changes on road systems based on current conditions, the reliability of the results depends on two main aspects according to [20]. The first aspect refers to the "data entry," with a correct interpretation of the data entry requirements, in order to achieve an appropriate data quality for the desired reliability of the results. The second aspect refers to the "output calibration," with the adjustment of model parameters to improve forecast, considering changes and influences with the passing of time and under various interventions. 
According to Yang et al. [21], different practices in construction processes, traffic diversifications and regional conditions generate potential sources of uncertainty when planning maintenance and rehabilitation interventions. Therefore, the search and update of data becomes a very important aspect to maintain the reliability of PMS. In this regard, several studies have carried out calibrations to the prediction models of HDM-4 to be adapted and utilized in PMS; for example, Bannour et al. [22] adapted structural failure models for conditions in Morocco; Jain et al. [23] calibrated pavement deterioration models for general network conditions in India; and Rodhe et al. [24] suggest a series of calibrations to improve the prediction of performance models in South Africa. Furthermore, Pantuso [25] used this model to integrate studies to assess pavement conditions in the implementation of PMS in Kazakhstan. On the other hand, various studies, such as those conducted by Tsunokawa and Ul-Islam [26], are focused on the definition of optimal M\&R strategies; also, Zaabar and Chatti [27] used calibrated systems to predict economic costs of users.

In addition, Geographic Information Systems (GIS) have been a useful tool in pavement management, because it allows the integration of different data, such as inventory of road networks, pavement conditions, and history of interventions, just to mention a few examples; as well as using this information in a PMS [28]. As a matter of fact, GIS have certain similarities with PMS because they have systems for collection, processing and presentation of information. Silva-Balaguera et al. [29] carried out a study that integrates multiple analyses of GIS and PMS, denoting that the combination of both systems allows cost optimization and the definition of prioritization of interventions; as well as, a combination of these systems allows time reduction in processing and updating of future data on road networks, as well as allowing access to historical and zoned road information.

\section{Materials and Methods}

\subsection{Study Area}

The Highway Centinela-La Rumorosa is managed by the Investment Trust Funds Administration (FIARUM for its acronym in Spanish) which is located in the municipalities of Mexicali and Tecate (Figure 1) belonging to Federal Highway no. 2. This road has separate bodies with different traces and topographic conditions during its route, both in ascent and descent, and is a total of 64 kilometers in length. From road stretch $0+000$ to $18+000$ is considered an urban area of the municipality of Mexicali, which has a flat topography and straight road sections. In the same way, occurring with road section $18+000$ to $42+000$ has, from $42+000$ to $64+000$, a mountainous topography with a considerable curve system.

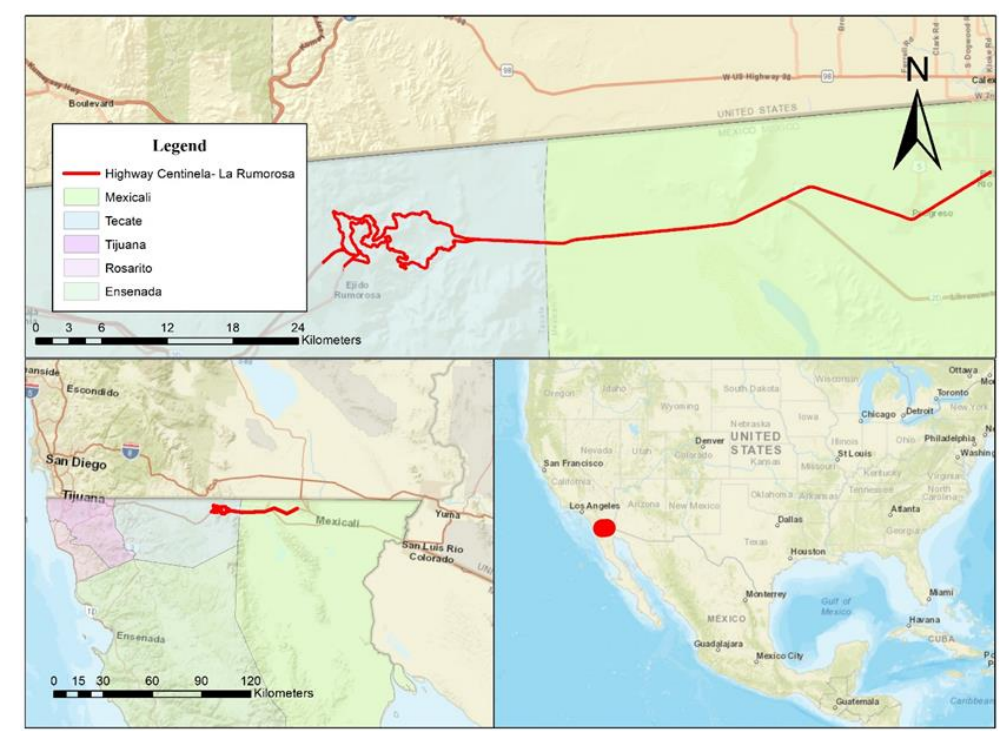

Figure 1. Centinela-La Rumorosa highway location. Source: Self-made. 
Although the section is in constant modernization, with an important planning effort by its managing agency, it has not been possible for it to have a preventive strategy for conservation and maintenance. This is due to the fact that the pavement structures have already fulfilled their life cycle in many of its sections, which is even accelerated due to the efforts generated by heavy traffic. That is why, as of 2014, in order to facilitate decision-making, a project which consisted in the analysis of surface and structural pavement conditions started, which resulted in the development of an annual interventions program and subsequently, in conservation efforts for the highway during the period 2014-2019. Furthermore, the analysis of the effects, as a result of these interventions, helped in improving conditions on the road section performance and to provide continuity to the highway maintenance and rehabilitation efforts after 2019.

\subsection{Analysis Methodology}

This methodology integrates surface and structural conditions data gathered in 2014, mainly the surface deterioration, roughness, rut and texture; as well as measures in structural performance, that is, stratigraphy, remaining life and fatigue data. Representative data of conditions in the study area, in a simulation process in order to determine maintenance rehabilitation work effects carried out to date that support future decision-making, guarantees a better performance for users of this highway. The structure of the model used in the current research work is presented below (Figure 2).
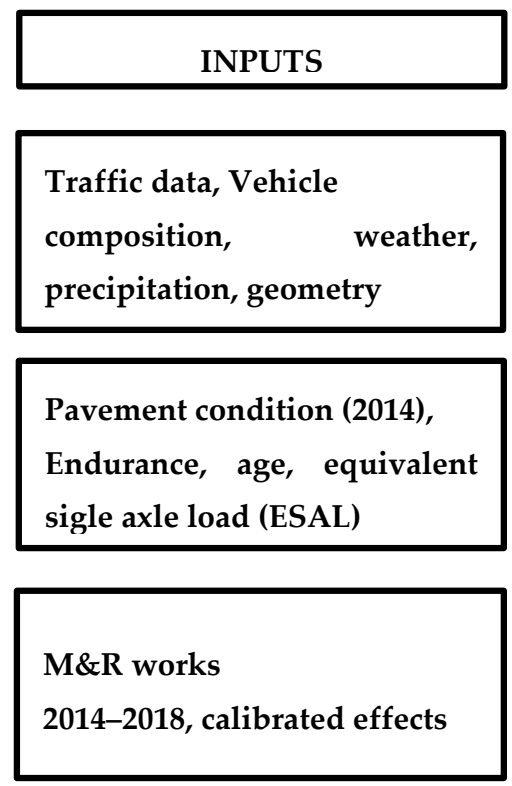

Post-jobs road surface, Traffic data, accidents data
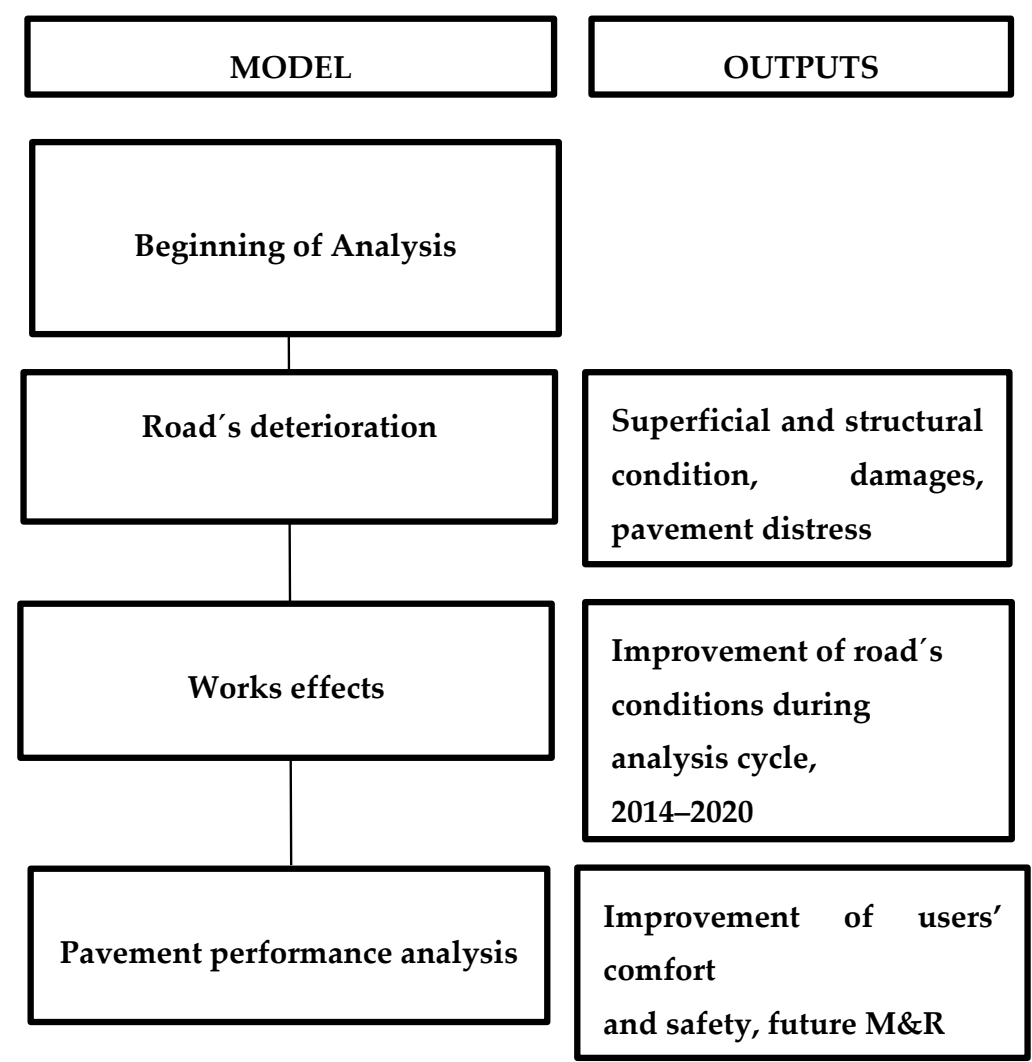

Figure 2. Methodology flowchart.

In the following, the steps of the methodology are listed:

1. In the beginning of analysis, representative data of the study area is collected.

2. To obtain the road's deterioration in 2014 , a pavement network inventory is created on a GIS software to obtain the superficial and structural condition of the pavement.

3. The works effect is carried out, to date, by simulation to obtain road conditions at the end of the analysis cycle. 
4. The improvement of highway performance is reflected in operational indicators like highway use, reduction of the number of accidents and the improvement of users' safety and comfort, through the serviceability index. Additionally, these results allow prioritizing future $M \& R$ interventions.

\subsection{Input Data}

It is established that the first input data should reflect pavement conditions regarding surface and structure. The surface analysis refers to an evaluation of surface faults through a pavement distress survey [30], as well as the measurement of two performance indicators, which are the International Roughness Index (IRI) and the Rut Depth (RD). For its part, the structural analysis refers to assessing the structure of the pavement, considering the measurement of thicknesses, quality of the materials that make it up and load capacity. Furthermore, an integral evaluation of the existing pavement is carried out in order to predict its useful life, from the point of view of deformations and fatigue capacities. This analysis considers the weather conditions in the study area and the projected traffic, and these situations resulted in the development of an annual interventions program, and with it, the implementation of maintenance works for the highway in the period 2014-2019. In addition, in order to integrate such data into a PMS, the effect of the work carried out, to date, is simulated.

\subsubsection{Pavement Characteristics}

For the pavement performance evaluation, several indicators are used, among the most used, the IRI and RD are evaluated. The first one refers an indicator that directly represents the functional condition of a pavement, and at the same time, constitutes a complementary indicator to divide the road network according to its structural capacity [31]. Likewise, HDM-4 program also has criteria established by ASHTOO to measure pavement surface condition. Therefore, data gathered, as well as the deterioration information, are classified according to these criteria (Table 1).

Table 1. Criteria for pavement conditions classification according to the degree of deterioration.

\begin{tabular}{ccccccc}
\hline $\begin{array}{c}\text { Grade of } \\
\text { Deterioration }\end{array}$ & $\begin{array}{c}\text { Cracking } \\
(\mathbf{\%})\end{array}$ & $\begin{array}{c}\text { Aggregate } \\
\text { Shedding } \\
(\mathbf{\%})\end{array}$ & $\begin{array}{c}\mathbf{N}^{\circ} \text { Potholes } \\
\text { per km }\end{array}$ & $\begin{array}{c}\text { Edge Break } \\
\left(\mathbf{m}^{2} \text { per km) }\right.\end{array}$ & $\begin{array}{c}\text { Average } \\
\text { Depth of } \\
\text { Ruts }(\mathbf{m m})\end{array}$ & $\begin{array}{c}\text { Roughness } \\
(\mathbf{m} \text { per km) }\end{array}$ \\
\hline New & 0 & 0 & 0 & 0 & 0 & 0 \\
Good & 0 & 1 & 0 & 0 & 2 & 2 \\
Fair & 5 & 10 & 0 & 10 & 5 & 6 \\
Poor & 15 & 20 & 5 & 100 & 15 & 8 \\
Bad & 25 & 30 & 50 & 300 & 25 & 6 \\
\hline
\end{tabular}

The structural characteristics of the layers that make up physical and mechanical pavement properties are gathered through surveys and laboratory tests, in accordance with the national regulations of the Secretariat of Communication and Transport (SCT) and ASTM. Finally, as part of the evaluation process of the existing pavement, a sub-section review strategy is carried out, with the purpose of identifying the particularities of the road, and thereby, defining the most damaged areas in need of some maintenance work in a timely manner. The final goal of this evaluation stage lies in obtaining the foreseeable pavement life, whether the asphalt layer is stressed, or some or all the layers that make it up are misshapen. To calculate the value of the foreseeable life, either in equivalent axes or translation in years, it is necessary to consider a series of data, such as: road type, project transit, layers, thicknesses, relative values of critical support, elastic or stiffness modulus and Poisson's ratio [32]. The calculation of these values is done by using the software Dispav-5 version 3.0, developed by UNAM Engineering Institute [33]. 


\subsubsection{Conditions of the Study Area}

The weather element is an aspect that must be taken into consideration in pavement design and evaluation, since weather directly affects the behavior in design and evaluation. Weather conditions modify the stiffness, due to the thermoplastic properties of the material that constitutes the asphalt layers of the flexible pavements [34]. It is important to mention that the referred highway presents a great variability in its weather conditions. Therefore, for climatological data analysis, three weather stations are used in order to gather temperature data; two of them provided by FIARUM, the case of FIARUM KM-42 and BAJACAL58; as well as another weather station obtained from the network of weather stations of CONAGUA, named station 2086. Station location data are established in Figure 3.

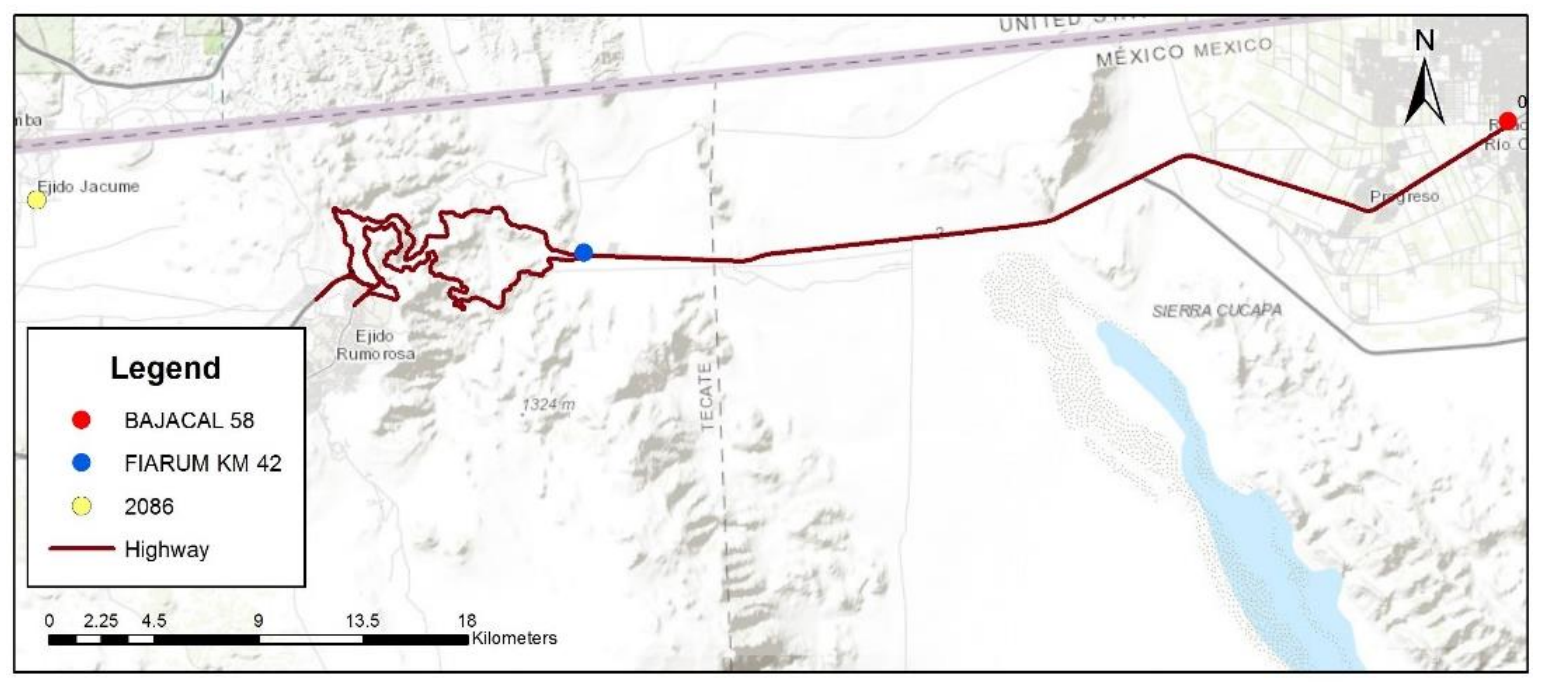

Figure 3. Location of weather stations.

\subsubsection{Traffic Data}

The vehicular traffic accounted for the direct solicitation to the structural system of distinct pavement [35]; for this reason, it is essential to quantify the magnitude of the loads by distributing the different types of vehicles and representative axes through vehicle composition, contact area and pressure distribution on the pavement. For the preparation of this document, the level of vehicular traffic is defined in equivalent single axle load (ESAL). These axes represent the unit of predicted damage induced by repetitions of a single axis of 8.2 tons with an inflation pressure of $5.8 \mathrm{~kg} / \mathrm{cm}^{2}$ in a time frame [14,36]. As Patrick Lavin [37] mentions, equivalent single axes are a key element in the description of the life and design of an asphalt pavement. Traffic effects on pavement conditions can be estimated by means of the Annual Average Daily Traffic (AADT), and the calculation of the equivalent axis corresponding to the traffic that circulated on the road from 2014 to 2018 through the following equation:

$$
\Sigma \mathrm{L}=(\mathrm{AADT}) \times(\mathrm{CD}) \times \sum_{\mathrm{i}=1}^{\mathrm{P}} \mathrm{C}_{\mathrm{i}}\left(\mathrm{w}_{\mathrm{i}} \sum \mathrm{C}_{\mathrm{dm}}+\left(1-\mathrm{w}_{\mathrm{i}}\right) \sum \mathrm{C}_{\mathrm{dv}}\right)
$$

where $\Sigma \mathrm{L}$ is the sum of equivalent axis of 8.2 tons expected at the end of the project; AADT corresponds to the annual average daily traffic; $\mathrm{CD}$ is the distribution coefficient per lane in decimals (generally 0.5 for two lane roads, 0.4 to 0.5 on four lane roads and 0.3 to 0.4 on six or more lanes); Cdm is the in damage coefficient of cargo vehicles (loaded) and Cdv corresponds to the damage coefficient of empty vehicles to calculate this coefficient's view, according to Corro et al. [38]; $\mathrm{Ci}$ is the directional distribution coefficient for each type of vehicle (i); and wi is the proportion of cargo vehicles (loaded) for each type of vehicle (i). 


\section{Results}

\subsection{Superficial and Structural Condition}

The classification results for surface damages in the year 2014, show that the most deteriorated road section is the descending one. This one presents bad conditions in $28.1 \%$ of its route being more critical in the mountainous area where there are steep slopes and curves; and in the first kilometers of this route that are considered part of the urban area. On the other hand, $70 \%$ of the ascending road section has good conditions. This information is presented in Figure 4.

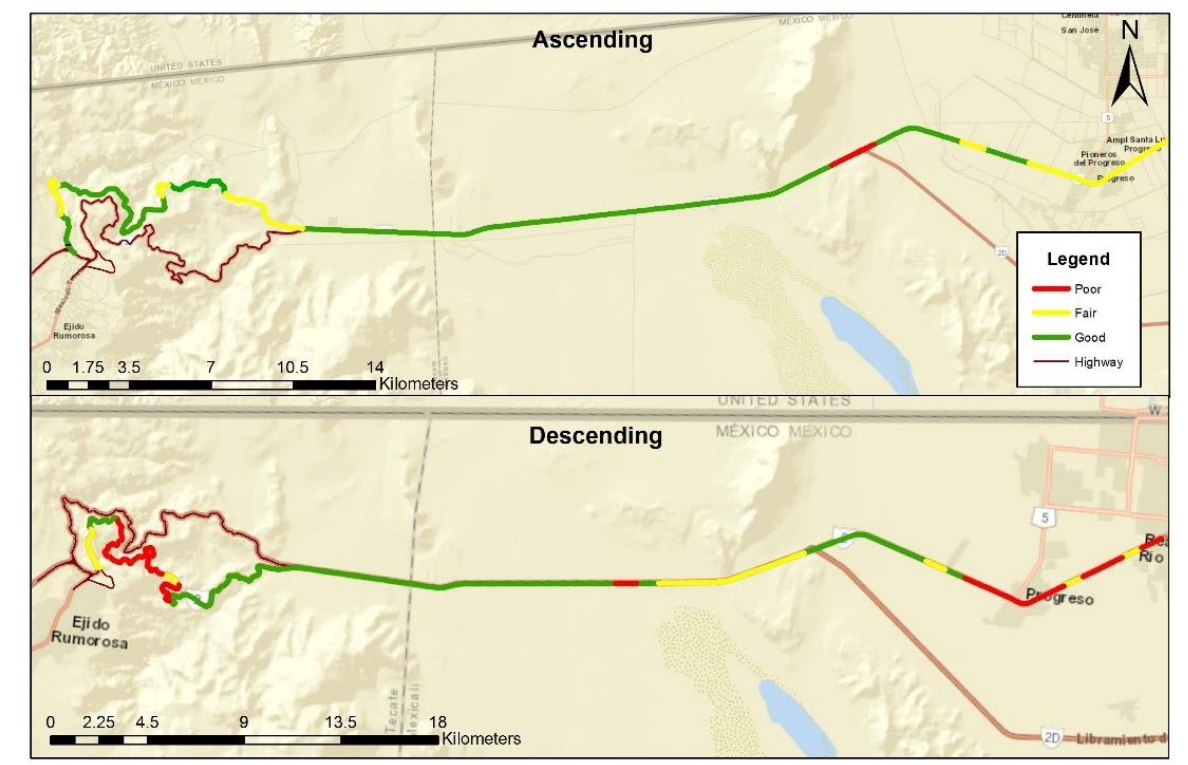

Figure 4. Highway surface conditions.

On the other hand, structural conditions analysis results reveal the points of the road network that show resistance deficiencies in some of the layers that make up the pavement structure. According to Figure 5, the ascending road section presents greater structural deficiencies, presenting these deficiencies in $37 \%$ of its route. Regarding the descent road section, there are deficiencies in $20 \%$ of the route. Nevertheless, the remaining life analysis revealed that these deficiencies do not require an immediate pavement total reconstruction, but a superficial treatment only.

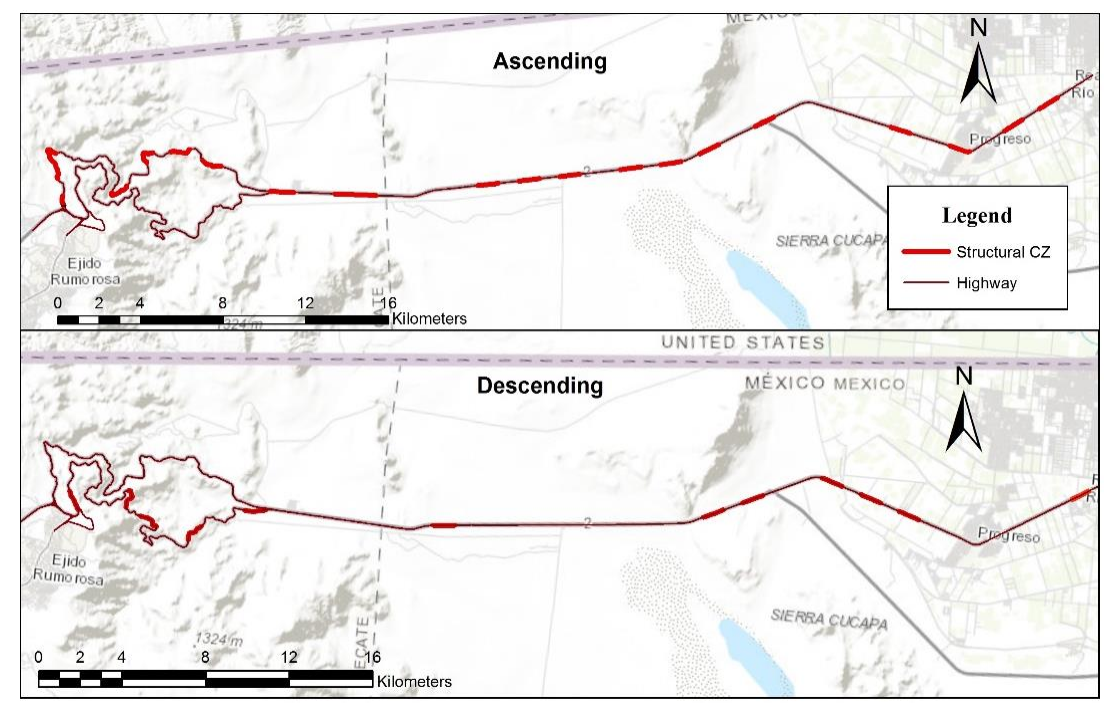

Figure 5. Structural conditions of the highway. 


\subsection{Definition of Intervention Priorities}

Once the information regarding surface and structure of the highway has been analyzed, critical points of the highway are identified. These critical points are values that are outside the minimum operating parameters established by SCT regulations for IRI and RD, as well as those ones established by the CMT book: characteristics of the materials IMT/SCT [39], for different layers that integrate the pavement structure. The summary of this analysis is presented in Table 2.

Table 2. Identification of critical points on the highway.

\begin{tabular}{|c|c|c|c|c|c|c|c|}
\hline \multicolumn{4}{|c|}{ Superficial } & \multicolumn{4}{|c|}{ Structural } \\
\hline \multicolumn{2}{|c|}{ Ascending } & \multicolumn{2}{|c|}{ Descending } & \multicolumn{2}{|c|}{ Ascending } & \multicolumn{2}{|c|}{ Descending } \\
\hline $\mathbf{K M}$ & Critical & KM & Critical & KM & Critical & KM & Critical \\
\hline 3 & IRI & 3 & IRI and RD & 2 & CBR HB & 1 & CBR HB \\
\hline 5 & IRI & 4 & IRI & 4 & CBR HB & 10 & CBR HB \\
\hline 6 & IRI & 5 & IRI & 7 & CBR HB & 12 & CBR HB \\
\hline 8 & IRI & 6 & IRI and RD & 10 & CBR HB & 14 & CBR HB \\
\hline 9 & IRI & 7 & PR & 17 & CBR HB & 18 & CBR HB \\
\hline 12 & IRI & 8 & IRI and RD & 20 & CBR HB & 20 & CBR HB \\
\hline 10 & IRI & 9 & IRI and RD & 22 & CBR HB & 33 & CBR HB \\
\hline 12 & IRI & 11 & IRI & 24 & CBR HB & 42 & CBR HB \\
\hline 17 & $\mathrm{RD}$ & 26 & IRI & 27 & CBR HB & 46 & CBR HB \\
\hline 18 & RD & 50 & IRI & 29 & CBR HB & 52 & CBRHB \\
\hline 43 & IRI & 51 & IRI & 31 & CBR HB & 54 & CBR HB \\
\hline 44 & IRI & 53 & IRI & 37 & CBR HB & 63 & CBR HB \\
\hline \multirow[t]{9}{*}{45} & IRI & 54 & IRI & 38 & CBR HB & & \\
\hline & & 55 & IRI & 41 & CBR HB & & \\
\hline & & 56 & IRI & 45 & CBR HB & & \\
\hline & & 57 & IRI & 47 & CBR HB, SG & & \\
\hline & & 58 & IRI & 49 & CBR HB & & \\
\hline & & 59 & IRI & 52 & CBR HB & & \\
\hline & & & & 58 & CBR HB & & \\
\hline & & & & 59 & CBR HB & & \\
\hline & & & & 61 & CBR HB & & \\
\hline
\end{tabular}

Note: Critical points establish deficiencies in the California Bearing Ratio (CBR) in some of the layers that make up the pavement; $\mathrm{HB}$ corresponds to the hydraulic base; SG corresponds to the subgrade layer.

As mentioned above, structural deficiencies do not require immediate reconstruction works. However, sections that are more likely to get damaged due to deformation or stress are shown for future interventions.

\subsection{Maintenance and Rehabilitation Work to Improve Highway Conditions}

Once the information on the field data has been analyzed, the work to be carried out in the intervention plan is determined. This plan takes into account works carried out from 2014 through 2019. However, most of the proposed works have already been executed by 2018 , with the exception of the first 18 kilometers of the highway, located in the urban area. It is worth mentioning that this section is administered by another local agency that has not carried out the proposed interventions. Works executed are presented below in Table 3.

According to the previous chart, three surface maintenance strategies were carried out. The first strategy was with slurry seal, which consists of applying a homogeneous liquid mixture of water, asphalt emulsion, mineral filler and well-graduated aggregate. The second strategy was with $40 \mathrm{~mm}$ overfolder works, which consists of the application of a tack coat and the placement of a dense granulometry layer. The third strategy was milling and re-construction, which refers to the removal of $100 \mathrm{~mm}$ of existing asphalt layer and placement of $50 \mathrm{~mm}$ of a new layer. 
Table 3. Maintenance work carried out on the highway between 2014 and 2018.

\begin{tabular}{|c|c|c|c|c|c|}
\hline \multicolumn{3}{|c|}{ Ascending } & \multicolumn{3}{|c|}{ Descending } \\
\hline Year & $\begin{array}{l}\text { Maintenance } \\
\text { Work }\end{array}$ & Chainage (km) & Year & $\begin{array}{l}\text { Maintenance } \\
\text { Work }\end{array}$ & Chainage $(\mathrm{km})$ \\
\hline 2015 & Overlay $40 \mathrm{~mm}$ & $\begin{array}{c}18+000 \text { to } \\
23+000\end{array}$ & 2015 & Overlay $40 \mathrm{~mm}$ & $\begin{array}{c}30+008 \text { to } \\
22+000\end{array}$ \\
\hline 2015 & Overlay $40 \mathrm{~mm}$ & $\begin{array}{c}33+642 \text { to } \\
35+850\end{array}$ & 2016 & $\begin{array}{l}\text { Mill and } \\
\text { replace } 50 \mathrm{~mm}\end{array}$ & $\begin{array}{c}60+000 \text { to } \\
64+000\end{array}$ \\
\hline 2015 & Overlay $40 \mathrm{~mm}$ & $\begin{array}{c}43+000 \text { to } \\
49+012\end{array}$ & 2016 & $\begin{array}{l}\text { Mill and } \\
\text { replace } 50 \mathrm{~mm}\end{array}$ & $\begin{array}{c}60+000 \text { to } \\
56+000\end{array}$ \\
\hline 2015 & Overlay $40 \mathrm{~mm}$ & $\begin{array}{c}60+000 \text { to } \\
61+405\end{array}$ & 2016 & $\begin{array}{l}\text { Mill and } \\
\text { replace } 50 \mathrm{~mm}\end{array}$ & $\begin{array}{c}56+000 \text { to } \\
52+000\end{array}$ \\
\hline 2016 & $\begin{array}{l}\text { Mill and } \\
\text { replace } 50 \mathrm{~mm}\end{array}$ & $\begin{array}{c}20+000 \text { to } \\
29+000\end{array}$ & 2016 & $\begin{array}{l}\text { Mill and } \\
\text { replace } 50 \mathrm{~mm}\end{array}$ & $\begin{array}{c}40+500 \text { to } \\
36+000\end{array}$ \\
\hline 2017 & $\begin{array}{l}\text { Mill and } \\
\text { replace } 50 \mathrm{~mm}\end{array}$ & $\begin{array}{c}20+000 \text { to } \\
29+000\end{array}$ & 2017 & Slurry seal & $\begin{array}{c}23+000 \text { to } \\
19+000\end{array}$ \\
\hline 2017 & Slurry seal & $\begin{array}{c}29+000 \text { to } \\
41+600\end{array}$ & 2017 & $\begin{array}{l}\text { Mill and } \\
\text { replace } 50 \mathrm{~mm}\end{array}$ & $\begin{array}{c}19+000 \text { to } \\
18+000\end{array}$ \\
\hline 2017 & $\begin{array}{l}\text { Mill and } \\
\text { replace } 50 \mathrm{~mm}\end{array}$ & $\begin{array}{c}41+600 \text { to } \\
42+500\end{array}$ & 2018 & $\begin{array}{l}\text { Mill and } \\
\text { replace } 50 \mathrm{~mm}\end{array}$ & $\begin{array}{c}60+000 \text { to } \\
48+500\end{array}$ \\
\hline 2017 & Slurry seal & $\begin{array}{c}49+000 \text { to } \\
53+500\end{array}$ & 2018 & $\begin{array}{l}\text { Mill and } \\
\text { replace } 50 \mathrm{~mm}\end{array}$ & $\begin{array}{c}48+500 \text { to } \\
45+300\end{array}$ \\
\hline 2017 & Overlay $40 \mathrm{~mm}$ & $\begin{array}{c}53+500 \text { to } \\
55+500\end{array}$ & 2018 & $\begin{array}{l}\text { Mill and } \\
\text { replace } 50 \mathrm{~mm}\end{array}$ & $\begin{array}{c}44+000 \text { to } \\
40+500\end{array}$ \\
\hline 2017 & Slurry seal & $\begin{array}{c}55+500 \text { to } \\
60+800\end{array}$ & 2018 & $\begin{array}{l}\text { Mill and } \\
\text { replace } 50 \mathrm{~mm}\end{array}$ & $\begin{array}{c}40+500 \text { to } \\
36+000\end{array}$ \\
\hline 2018 & $\begin{array}{l}\text { Mill and } \\
\text { replace } 50 \mathrm{~mm}\end{array}$ & $\begin{array}{l}18+000 \text { to } \\
20+000\end{array}$ & 2018 & $\begin{array}{l}\text { Mill and } \\
\text { replace } 50 \mathrm{~mm}\end{array}$ & $\begin{array}{c}35+900 \text { to } \\
34+800\end{array}$ \\
\hline 2018 & Slurry seal & $\begin{array}{c}20+000 \text { to } \\
29+000\end{array}$ & 2018 & Slurry seal & $\begin{array}{c}34+800 \text { to } \\
32+000\end{array}$ \\
\hline 2018 & $\begin{array}{l}\text { Mill and } \\
\text { replace } 50 \mathrm{~mm}\end{array}$ & $\begin{array}{c}29+000 \text { to } \\
41+600\end{array}$ & 2018 & $\begin{array}{l}\text { Mill and } \\
\text { replace } 50 \mathrm{~mm}\end{array}$ & $\begin{array}{c}31+290 \text { to } \\
24+280\end{array}$ \\
\hline 2018 & Slurry seal & $\begin{array}{c}42+600 \text { to } \\
49+000\end{array}$ & 2018 & Slurry seal & $\begin{array}{c}24+500 \text { to } \\
23+300\end{array}$ \\
\hline 2018 & $\begin{array}{l}\text { Mill and } \\
\text { replace } 50 \mathrm{~mm}\end{array}$ & $\begin{array}{c}49+500 \text { to } \\
53+600\end{array}$ & 2018 & $\begin{array}{l}\text { Mill and } \\
\text { replace } 50 \mathrm{~mm}\end{array}$ & $\begin{array}{c}23+100 \text { to } \\
18+000\end{array}$ \\
\hline
\end{tabular}

\subsection{Highway Improvement Conditions Analysis}

Results in the improvement of highway performance conditions are reflected in different operational indicators. This document takes into account increase in highway use, reduction of the number of accidents and the improvement of users' safety and comfort, through the serviceability index.

In terms of the increase in highway use and registered accidents, Figure 6 presents that from 2008 through 2015, vehicle growth rate is negative. In other words, the number of vehicles on the highway is less every year. However, since the intervention plan came into effect, the average vehicle growth up to 2018 is $5 \%$ per year, having its biggest rise in 2016. Despite this growth, the number in annual accidents has not increased proportionally regarding that growth. As a matter of fact, it is observed that in the last ten years, an average of 180 annual accidents have been maintained.

In order to measure the effect of executed works in pavement performance, a simulation of the proposed works and its impact regarding users' safety and comfort is carried out. Starting on the Present Serviceability Index (PSI), this concept was defined by AASTHO (American Association of State Highway Officials) [14] to assess the pavement's functional condition according to the user's perception. This index is calculated through its relationship with the IRI proposed by Al-Omari and Darter [40] for asphalt pavements using the following equation:

$$
\text { PSI }=5 * \mathrm{e}^{-0.24+\mathrm{IRI}}
$$

where PSI is the Present Serviceability Index and IRI is the International Roughness Index. 


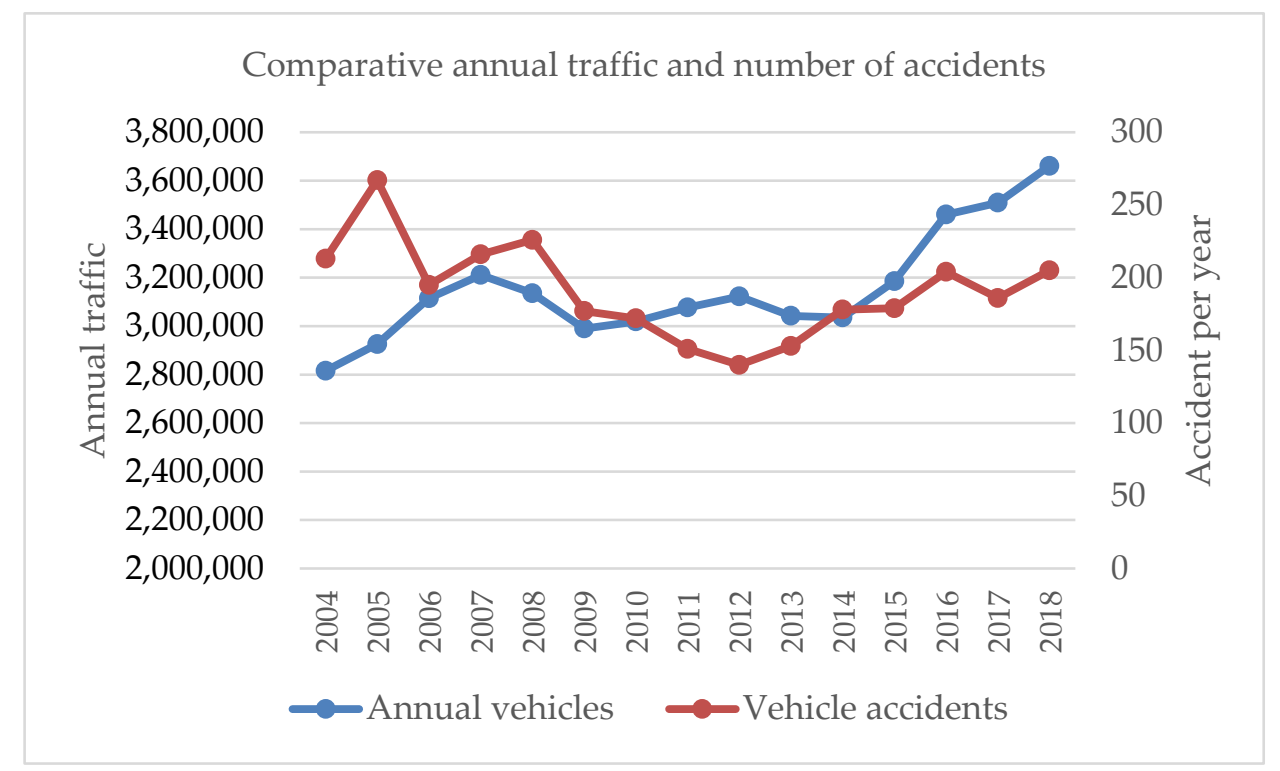

Figure 6. Highway traffic number of accidents comparative.

Simulation of works on the road section were carried out with the Infrastructure Management System HDM-4 Version 1.03, using the Work Effects (WE) module, which includes mathematical relationships for modeling of road deterioration and for the effects of works in pavement conditions improvement. Prediction model calibration is carried out through field studies and existing literature related to the impacts of maintenance and rehabilitation strategies [41], and conditions of the study area and calculation of real equivalent axis using Equation (1) per year from 2014 through 2018. Figure 7 shows the simulation in the works effects regarding pavement performance improvement, through the PSI. These results show that the interventions positively influenced highway performance improvement. Due to the simulated levels with the project, the improvement remains in the range from regular to good by 2020. Additionally, these results allow prioritizing future interventions in both highway routes. According to Morova et al. [42], half of the AASHTO study evaluators determined that a range of 3.0 in the PSI is considered acceptable and less than 2.5 is unacceptable. Therefore, the highway has good performance conditions and will maintain this characteristic in years to come.

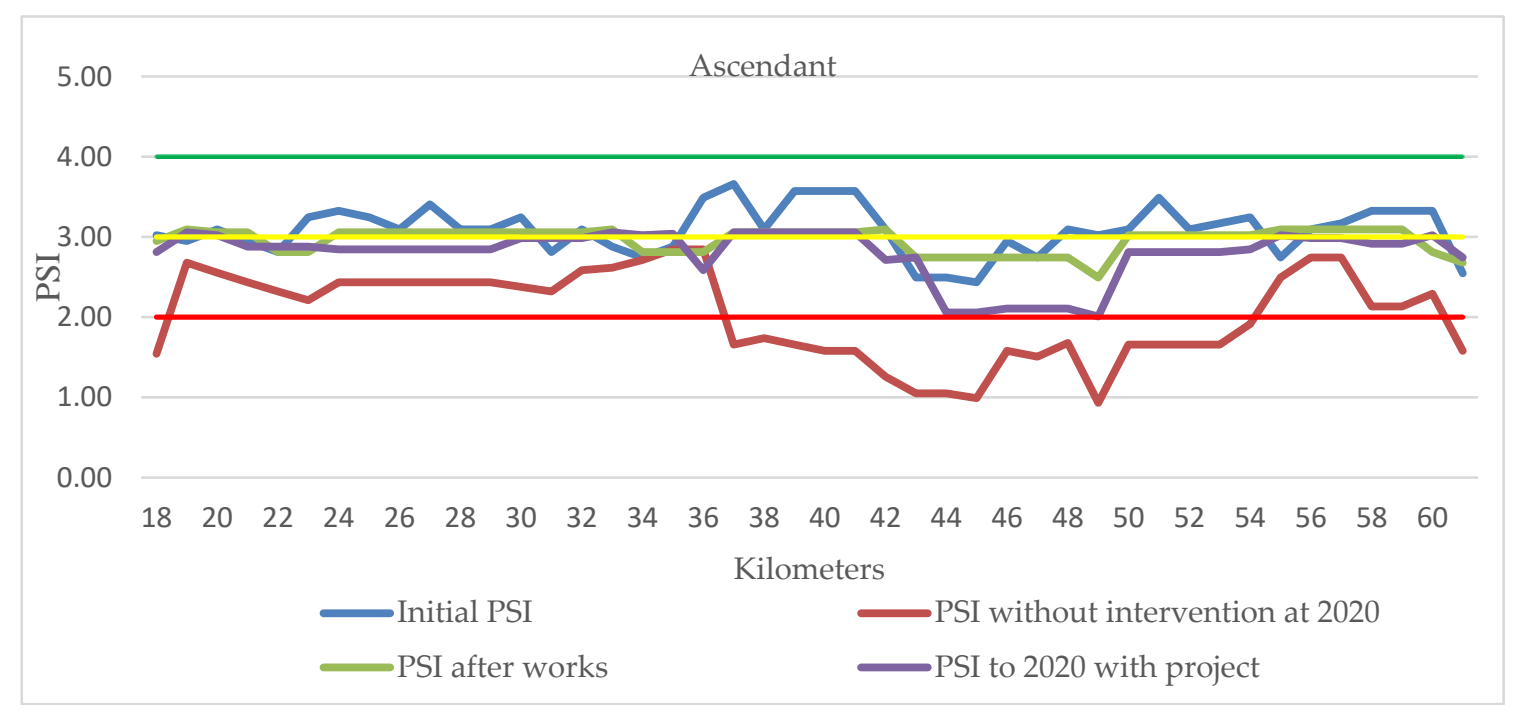

(a) Simulation of works and performance in ascending road section.

Figure 7. Cont. 


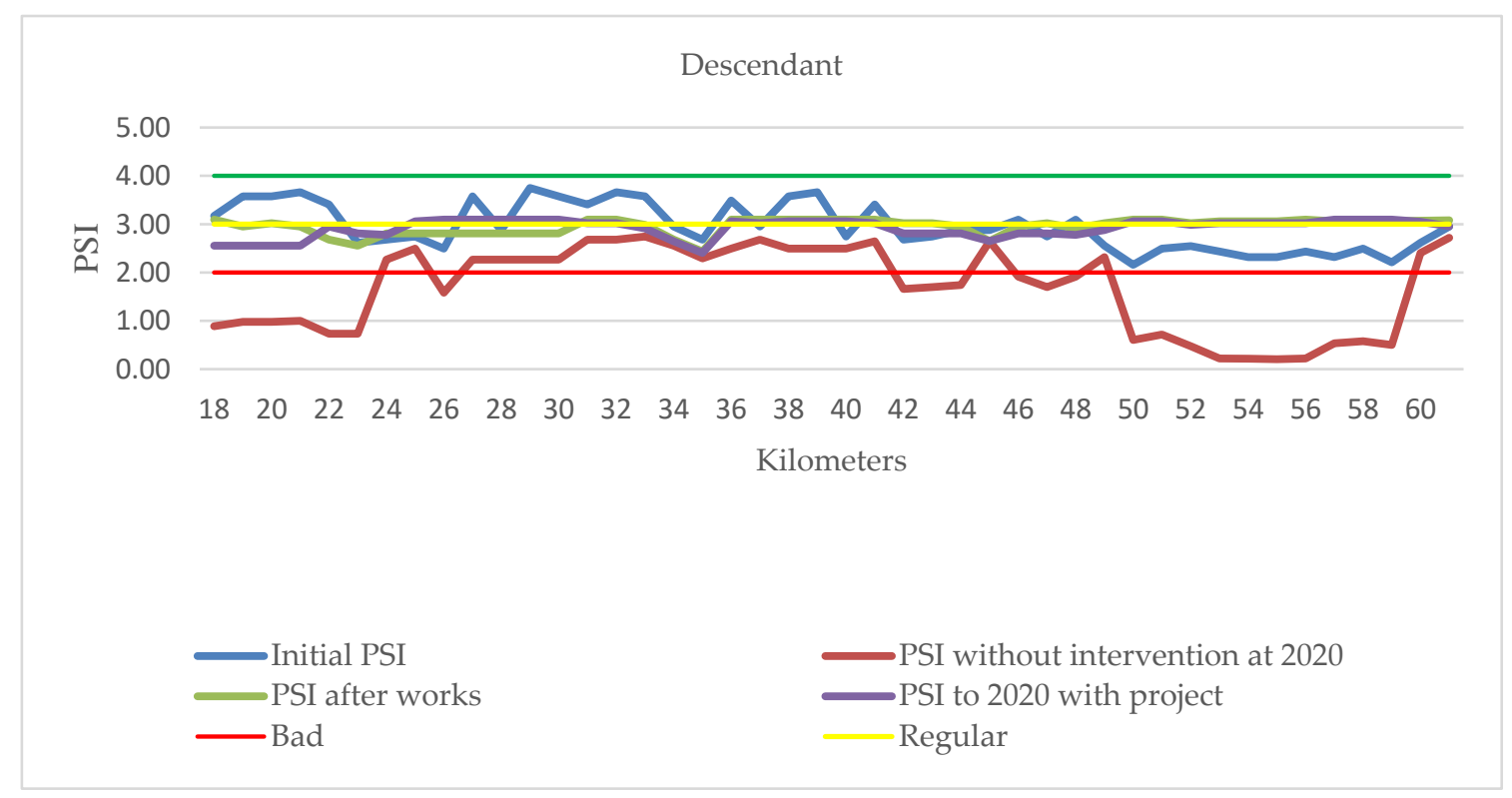

(b) Simulation of works and performance in descending road section.

Figure 7. Highway performance improvement simulation.

\section{Discussion and Conclusions}

Evaluating surface and structural conditions of the existing pavement is essential, in order to determine the $M \& R$ actions that provide greater benefits to decision makers and road users.

Surface conditions directly influence in service and safety road section levels. This is because the quality of the bearing is the main factor associated with user safety and comfort. On the other hand, the correct pavement operation depends on materials and strength characteristics that build up the structure, since these structures define deformation magnitude, caused by the conditions of the study area, such as the temperature of the area and traffic characteristics.

Once current highway conditions have been gathered, it is possible to calculate the foreseeable life of both the asphalt layer and structure in order to ensure that all the proposed works are carried out within the necessary time. For the contemplated cycle in the intervention plan, it is not necessary to carry out total pavement reconstruction works, so that the intervention proposals include surficial works only. However, this analysis allows the identification of the most damaged areas in need of total pavement maintenance works in future intervention plans.

Some of the proposed interventions were not carried out based on the intervention plan, particularly in the first $18 \mathrm{~km}$ of the highway, which are administered by another agency. Therefore, its immediate intervention is recommended, because this section has superficial and structural deficiencies. Although the prediction models allow an overview of the pavement conditions, it is necessary to obtain updated data in order to optimize the prediction models.

Regarding safety, the main cause of accidents on the highway is attributed to the human factor according to Farooq et al. [10], reflected in overturns, from exiting due to speeding, just to mention the most frequent ones. However, infrastructure characteristics improvements that influence the road safety of road traffic are highly effective. According to the results, although the traffic increased exponentially from the moment of highway improvement conditions, the number of annual accidents did not. However, pavement M\&R interventions address only rolling-related factors, so it is necessary to review the path, slope or degree of curvature, as well as interventions related to the improvement of geometric design and regulation of road marking and safety devices. 
In general, results of the serviceability analysis show that interventions carried out on the highway improved the comfort and safety of users, according to the PSI. Additionally, some road sections already maintained favorable service levels, so the interventions helped preserve these conditions.

According to the literature review, the concept of sustainability can be applied at all stages of the pavement cycle. However, this proposal focuses on two stages. First, in the maintenance stage, through the improvement in the allocation of resources in M\&R activities. Second, in the operation phase, through the improvement in the use of the highway and its interaction with the user.

It is concluded that the proposed planning model contributes to the improvement of highway performance, since it allows planning and administering the allocation of resources in making appropriate maintenance and rehabilitation decisions. Additionally, it allows to generate valuable inputs for PMS implementation. The foregoing allows road management agencies in developing countries to provide a quality transport system to users.

Author Contributions: M.M.-A. software, writing-review, original draft preparation, investigation; A.M.-M. supervision, editing, project administration; L.G. writing-review, editing, validation. All authors have read and agreed to the published version of the manuscript.

Funding: This research received no external funding.

Acknowledgments: We sincerely appreciate the Engineering Faculty of the Universidad Autónoma de Baja California and Fideicomiso Tramo Carretero Centinela-Rumorosa (FIARUM), for their support in this study.

Conflicts of Interest: The authors declare no conflict of interest.

\section{References}

1. Ozer, H.; Al-Qadi, I.L.; Harvey, J. Strategies for Improving the Sustainability of Asphalt Pavements:[techbrief]. 2016. Available online: https://rosap.ntl.bts.gov/view/dot/38346. (accessed on 7 October 2019).

2. Wolters, A.; Zimmerman, K.; Schattler, K.; Rietgraf, A. Implementing Pavement Management Systems for Local Agencies-State-of-the-Art/State-of-the-Practice. 2011. Available online: https://apps.ict.illinois.edu/ projects/getfile.asp?id=3053 (accessed on 5 September 2019).

3. Martínez, I.; Ríos, J. Sistema de administración de pavimentos sobre la ciudad de Bogotá. 2010. Available online: https://www.academia.edu/15014853/Modelo (accessed on 5 September 2019).

4. Luo, G.Z.; Fu, J.S.; Yan, P. Highway Construction Based on Sustainable Concept; Advanced Materials Research; Trans Tech Publication: Zurich, Switzerland, 2013; pp. 4086-4090.

5. Muench, S.; Anderson, J.; Hatfield, J.; Koester, J.; Söderlund, M.; Weiland, C. Greenroads Manual v1. 5; University of Washington: Seattle, WA, USA, 2011.

6. Mendoza Sánchez, J. Criterios de Sustentabilidad Para Carreteras en México; Publicacion Tecnica; Instituto Mexicano del Transporte: Pedro Escobedo, Mexico, 2014.

7. Bryce, J.; Brodie, S.; Parry, T.; Presti, D.L. A systematic assessment of road pavement sustainability through a review of rating tools. Resour. Conserv. Recycl. 2017, 120, 108-118. [CrossRef]

8. Mao, X.; Wang, J.; Yuan, C.; Yu, W.; Gan, J. A dynamic traffic assignment model for the sustainability of pavement performance. Sustainability 2019, 11, 170. [CrossRef]

9. Corriere, F.; Rizzo, A. Sustainability in Road Design: A Methodological Proposal for the Drafting of Guideline. Procedia-Soc. Behav. Sci. 2012, 53, 39-48. [CrossRef]

10. Farooq, D.; Moslem, S.; Duleba, S. Evaluation of Driver Behavior Criteria for Evolution of Sustainable Traffic Safety. Sustainability 2019, 11, 3142. [CrossRef]

11. Yang, Y.; Easa, S.M.; Lin, Z.; Zheng, X. Evaluating highway traffic safety: An integrated approach. J. Adv. Transp. 2018, 2018. [CrossRef]

12. Demasi, F.; Loprencipe, G.; Moretti, L. Road safety analysis of urban roads: Case study of an Italian municipality. Safety 2018, 4, 58. [CrossRef]

13. Montgomery, R.; Schirmer, H., Jr.; Hirsch, A. Improving Environmental Sustainability in Road Projects. 2015. Available online: https://static1.squarespace.com/static/5812be0d59cc68fbc0eebd4c/t/591a3e2ff7e0abb702713d7a/ 1494892088186/Improving_Environmental_Sustainability_in_Road_Projects_2015.pdf (accessed on 9 October 2019).

14. AASHTO. AASHTO Guide for Design of Pavement Structures, 1993; American Association of State Highway and Transportation Officials: Washington, DC, USA, 1993. 
15. Gerber, A.D.; Miller, T.D.; Richardson, M.J. Implementation and Calibration of a Laser Crack Measurement System for the Delaware Department of Transportation's Pavement Management Program. In Proceedings of the Transportation Research Board 97th Annual Meeting, Washington, DC, USA, 7-11 January 2018.

16. Cottrell, W.D.; Bryan, S.; Chilukuri, B.R.; Kalyani, V.; Stevanovic, A.; Wu, J. Transportation infrastructure maintenance management: Case study of a small urban city. J. Infrastruct. Syst. 2009, 15, 120-132. [CrossRef]

17. Loprencipe, G.; Pantuso, A.; Di Mascio, P. Sustainable pavement management system in urban areas considering the vehicle operating costs. Sustainability 2017, 9, 453. [CrossRef]

18. Corazza, M.V.; Di Mascio, P.; Moretti, L. Managing sidewalk pavement maintenance: A case study to increase pedestrian safety. J. Traffic Transp. Eng. 2016, 3, 203-214. [CrossRef]

19. Attoh-Okine, N.; Adarkwa, O. Pavement Condition Surveys-Overview of Current Practices; Delaware Center for Transportation, University of Delaware: Newark, DE, USA, 2013.

20. Bennett, C.R.; Paterson, W.D. Volume 5: A guide to calibration and adaptation. In HDM-4: Highway Development and Management Series; 2000; Available online: http://piarc.rmto.ir/DocLib4/Volume5.pdf (accessed on 24 July 2019).

21. Yang, Y.; Huang, L.; Wang, J.; Xia, Y. Research on Reference Indicators for Sustainable Pavement Maintenance Cost Control through Data Mining. Sustainability 2019, 11, 877. [CrossRef]

22. Bannour, A.; Elomari, M.; El Khadir, L.; Afechkar, M.; Lamrini, B.; Joubert, P. Calibration Study of HDM-4 Model of Structural Cracking Models for Flexible Pavements in Moroccan Context. 2015. Available online: https:/www.researchgate.net/publication/283349130_Calibration_study_of_HDM-4_Model_ of_structural_cracking_models_for_flexible_pavements_in_Moroccan_Context (accessed on 24 July 2019).

23. Jain, S.; Parida, M.; Thube, D. HDM-4 based optimal maintenance strategies for low-volume roads in India. Road Transp. Res. J. Aust. New Zealand Res. Pract. 2007, 16, 3.

24. Rohde, G.T.; Jooste, F.; Sadzik, E.; Henning, T. The Calibration and Use of HDM-IV Performance Models in a Pavement Management System. In Proceedings of the Fourth International Conference on Managing Pavements, Durban, South Africa, 17-21 May 1998.

25. Pantuso, A.; Loprencipe, G.; Bonin, G.; Teltayev, B.B. Analysis of pavement condition survey data for effective implementation of a network level pavement management program for Kazakhstan. Sustainability 2019, 11, 901. [CrossRef]

26. Tsunokawa, K.; Ul-Islam, R. Optimal pavement design and maintenance strategy for developing countries: An analysis using HDM-4. Int. J. Pavement Eng. 2003, 4, 193-208. [CrossRef]

27. Zaabar, I.; Chatti, K. Calibration of HDM-4 models for estimating the effect of pavement roughness on fuel consumption for US conditions. Transp. Res. Rec. 2010, 2155, 105-116. [CrossRef]

28. Smadi, O. Quantifying the Benefits of Pavement Management. In Proceedings of the 6th International Conference on Managing Pavements, Brisbane, Australia, 19-24 October 2004.

29. Silva-Balaguera, A.; Leguizamón, O.D.; Valiente, L.L. Gestión de pavimentos basado en Sistemas de Información geográfica (SIG): Una revisión. Ing. Solidar. 2018, 14, 26.

30. Ragnoli, A.; De Blasiis, M.R.; Di Benedetto, A. Pavement distress detection methods: A review. Infrastructures 2018, 3, 58. [CrossRef]

31. Vera, I.; Thenoux, G.; Solminihac, H.; Echaveguren, T. Modelo de evaluación técnica del desempeño del mantenimiento de pavimentos flexibles. Rev. De La Construcción 2010, 9, 76-88. [CrossRef]

32. Corro, S.; Prado, G.; Rangel, A. Diseño Estructural de Pavimentos Asfálticos, Incluyendo Carreteras de Altas Especificaciones. 1999. Available online: https://datosabiertos.unam.mx/CCUD_DOR_WS-war/resources/ doil/4945567d96f6492b (accessed on 19 July 2019).

33. Corro, S.; Castillo, G.; Ossa, A.; Hernández, A.; Mandujano, D.; Hernández, F.; Arizaga, S. Manual: Dispav-5, Versión 3.0. Actualización del Sistema Para el Diseño Estructural de Pavimentos Asfálticos, Incluyendo Carreteras de Altas Especificaciones. 2014. Available online: https://aplicaciones.iingen.unam. $\mathrm{mx} /$ consultasspii/DetallePublicacion.aspx?id=4972 (accessed on 19 July 2019).

34. Valdés, G.; Pérez-Jiménez, F.; Martinez, A. Influencia de la temperatura y tipo de mezcla asfáltica en el comportamiento a fatiga de los pavimentos flexibles. Rev. De La Construcción 2012, 11, 87-100.

35. Garnica Anguas, P.; Correa, Á. Conceptos Mecanicistas en Pavimentos; Instituto Mexicano del Transporte: Pedro Escobedo, Mexico, 2004.

36. Team, B. Comprehensive Truck Size and Weight (TSEW) Study Phase 1-Synthesis; Federal Highway Administration, US Department of Transportation: Columbus, OH, USA, 1995. 
37. Lavin, P. Asphalt Pavements: A Practical Guide to Design, Production and Maintenance for Engineers and Architects; CRC Press: Boca Raton, FL, USA, 2003.

38. Corro, S.; Magallanes, R. Instructivo Para Diseño Estructural de Pavimentos Flexibles Para Carreteras; Instituto de Ingeniería UNAM: Mexico City, Mexico, 1981.

39. SCT; CMT. Características de los Materiales. 2008. Available online: https://normas.imt.mx/normativa/NCMT-4-04-08.pdf (accessed on 6 June 2019).

40. Al-Omari, B.; Darter, M.I. Relationships between International Roughness Index and Present Serviceability Rating. 1994. Available online: https://www.researchgate.net/publication/303142433_Relationships_between_ international_roughness_index_and_present_serviceability_rating (accessed on 11 October 2019).

41. Cole, M.; Geib, J. MnDOT's Experience: Efforts to Improve Micro Surfacing Performance. Available online: https://www.dot.state.mn.us/materials/pavementpreservation/mndotexperiences/documents/ EffortstoImproveMicroSurfacingPerformance.pdf (accessed on 20 September 2019).

42. Morova, N.; Serín, S.; Terzi, S.; Saltan, M. Prediction of the pavement serviceability ratio of rigid highway pavements by artificial neural networks. İleri Teknol. Bilimleri Derg. 2013, 2, 12-25.

(C) 2019 by the authors. Licensee MDPI, Basel, Switzerland. This article is an open access article distributed under the terms and conditions of the Creative Commons Attribution (CC BY) license (http://creativecommons.org/licenses/by/4.0/). 